\title{
Interleukin 6 inhibition by triptolide prevents inflammation in a mouse model of ulcerative colitis
}

\author{
HAIFENG ZHANG ${ }^{1,2}$ and WEICHANG CHEN ${ }^{1}$ \\ ${ }^{1}$ Department of Gastroenterology, The First Affiliated Hospital of Soochow University, Soochow, Jiangsu 215006; \\ ${ }^{2}$ Department of Infectious Diseases, Affiliated Hospital of Nantong University, Nantong, Jiangsu 226001, P.R. China
}

Received August 5, 2016; Accepted April 21, 2017

DOI: $10.3892 / \mathrm{etm} .2017 .4778$

\begin{abstract}
The present study aimed to assess interleukin (IL)-6 expression in a murine model of ulcerative colitis (UC) induced by dextran sulfate sodium (DSS) and its potential association with the anti-colitis effects of triptolide (TL). Serum IL-6 levels were measured by ELISA. IL-6 gene expression levels in colonic mucosa specimens were assessed by reverse-transcription quantitative PCR and protein expression was evaluated by western blot analysis and immunohistochemistry. The expression of IL-6 was weak in mucosa specimens from normal control animals and upregulated in DSS-induced mice. In model mice treated with TL $(0.4$ and $0.6 \mathrm{mg} / \mathrm{kg})$, dexamethasone or mesalazine, IL- 6 expression was significantly reduced compared with that in model mice treated with normal saline or propylene glycol $(\mathrm{P}<0.05)$, while TL at $0.2 \mathrm{mg} / \mathrm{kg}$ did not elicit any significant inhibitory effect. There was no significant difference among TL $(0.4 \mathrm{mg} / \mathrm{kg}$ and $0.6 \mathrm{mg} / \mathrm{kg})$, mesalazine and dexamethasone treatments $(\mathrm{P}>0.05)$ in terms of IL-6 expression or histological score. The results of the present study indicated that IL-6 was overexpressed in a mouse model of UC and was involved in disease progression. In addition, TL exerted therapeutic effects in UC through inhibition of IL-6 expression.
\end{abstract}

\section{Introduction}

Studies have reported that immunological factors have a vital role in ulcerative colitis (UC), with other parameters, such as mental state, environment, irritability and free radical damage, are all involved in UC progression $(1,2)$. Numerous cytokines contribute to non-specific inflammation induced by the above factors in susceptible individuals. Multiple pro-inflammatory cytokines, including tumor necrosis factor (TNF)- $\alpha$, interleukin (IL)-6, IL-8 and IL-17, have been reported to have a

Correspondence to: Dr Weichang Chen, Department of Gastroenterology, The First Affiliated Hospital of Soochow University, 188 Shizi Street, Soochow, Jiangsu 215006, P.R. China E-mail: weichangchen@126.com

Key words: interleukin-6, triptolide, ulcerative colitis pivotal role in the pathogenesis of UC. IL-6 is generated by mononuclear macrophages, fibroblasts, endothelial cells, $\mathrm{T}$ cells and B cells, which possess various biological properties (3-7). Previous studies have demonstrated that IL-6 was overexpressed in inflammatory bowel mucosa, accompanied with IL-1, IL-17 and TNF- $\alpha$, leading to the occurrence of inflammation in UC $(8,9)$.

Triptolide (TL), a diterpenoid, is produced by the plant Tripterygium wilfordii. TL is known as a drug with marked pharmacological activities, including anti-inflammatory and immunomodulatory properties as well as improvement of the microcirculation; it inhibits the proliferation of various types of cancer cell and enhances tumor sensitivity to chemotherapy (10-27). In the present study, the expression patterns of IL-6 in a mouse model of UC model were assessed, as well as association between the anti-colitis effects of TL and IL-6 levels.

\section{Materials and methods}

Animals and colitis modeling. A total of 80 female BALB/c mice (age, 4-6 weeks; weight, 20-24 g) were obtained from the Animal Center of the Medical College of Nantong University (Nantong, China). They were raised in the Animal Center of Nantong University (Nantong, China) for 2 weeks at $22-24^{\circ} \mathrm{C}$ and $49 \%$ humidity with a 12 -h light/dark cycle and were fed a mixed-feed formula and had ad libitum access to distilled drinking water. All animal experiments were performed according to the Guide for the Care and Use of Laboratory Animals promulgated by the National Research Council, and supported by the Chinese National Committee for the Use of Experimental Animals for Medical Purposes, Jiangsu Branch (Nanjing, China). The study was approved by the Ethics Committee of the Affiliated Hospital of Nantong University (Nantong, China).

According to the method by Stevceva et al (28) from 2001, a mouse model of UC was established using dextran sulfate sodium (DSS; MP Biomedicals, Santa Ana, CA, USA). A total of 80 female BALB/c mice were stochastically divided into eight groups and housed in separate cages (10 mice per cage). The eight groups were designated as Group A-H. Group A was composed of non-treated sham mice; groups B-H contained DSS-induced model animals. Mice in group B were injected $0.2 \mathrm{ml}$ normal saline intraperitoneally once daily; group 
$\mathrm{C}$ received $0.2 \mathrm{ml} 20 \%$ propylene glycol as vehicle control daily, also intraperitoneally. Groups D-F were intraperitoneally injected daily with TL (Zelang Medical Science and Technology, Nanjing, China) dissolved in $20 \%$ propylene glycol at $0.20 \mathrm{mg} / \mathrm{kg}$ (TL1), $0.40 \mathrm{mg} / \mathrm{kg}$ (TL2) and $0.60 \mathrm{mg} / \mathrm{kg}$ (TL3). Group G was intraperitoneally injected with dexamethasone (Sichuan Guangda Pharmaceutical Co., Ltd., Pengzhou, China) dissolved in normal saline at a daily dose of $0.1 \mathrm{mg} / \mathrm{kg}$, and group $\mathrm{H}$ was administered mesalazine (Ipsen Ltd., Slough, UK) dissolved in water by oral gavage at a daily dose of $20 \mathrm{mg} / \mathrm{kg}$.

Evaluation of DSS-induced UC in mice. To assess the severity of colitis, the mice were monitored daily for activity, weight, dietary intake, stool properties and hematochezia. According to the standard by Murano et al (29), the DAI score was calculated as follows: DAI=(score of body weight loss + score of stool properties + score of hematochezia) $/ 3$.

Macroscopic score. At day 8, the mice were sacrificed by cervical dislocation and sectioned along the mesenteric junction to expose the intestinal cavity. After washing and drying, the collected intestinal wall was spread and fixed for visual inspection of inflammation and ulcer formation. The disease status was evaluated using the criteria by Ekström (30).

Histological score. Colonic tissue specimens were paraffin-embedded and then stained with hematoxylin and eosin (H\&E). The level of inflammation was evaluated by two independent pathologists according to a well-established scoring system (31).

Immunohistochemistry. Tissue samples were stained according to the manufacturer's protocol using and immunohistochemistry kit (cat. no. ab64261; Abcam, Cambridge, MA, USA), and the stained sections were analyzed by microscopy. To avoid possible technical errors, immunostaining data were evaluated by two independent pathologists. IL-6-positive cells (anti-IL-6 antibody; cat. no. ab7737; Abcam) were stained a brown/yellow color, ten high-power fields were randomly selected in each sample, with at least 500 cells counted. The following scoring system was employed for density evaluation: 0 , no staining; 1 , weak staining; 2 , moderate staining; 3 , strong staining. In addition, the extent of staining was recorded as follows: $0,<1 \% ; 1,1-25 \% ; 2,26-50 \% ; 3,51-75 \% ; 4,>75 \%$. IL-6 expression was evaluated by the two scales. The final score was obtained by multiplication of the two scores.

ELISA. The blood was obtained from the mice following scarification. IL-6 levels in plasma were measured using ELISA kits purchased from Thermo Fisher Scientific, Inc. (Waltham, MA, USA). ELISA was performed according to the manufacturer's instructions. The optical density was measured at a wavelength of $450 \mathrm{~nm}$ using a microtiter plate reader (Luwen Biological Technology Co., Ltd., Shanghai, China). The final results were expressed as $\mathrm{pg} / \mathrm{ml}$.

Reverse-transcription quantitative polymerase chain reaction $(R T-q P C R)$ analysis. Total RNA from the colonic mucosa was extracted according to standard TRIzol RNA isolation instructions (Invitrogen; Thermo Fisher Scientific, Inc.) and evaluated with a spectrophotometer for quantity and purity. The RT reaction was performed for $15 \mathrm{~min}$ at $37^{\circ} \mathrm{C}$. Forward and reverse primer sequences used to amplify IL- 6 and $\beta$-actin were synthesized by the Sangon Biotech Co., Ltd. (Shanghai, China). The primers for IL-6 were as follows: Forward, 5'-GGA ATTCGTGGAAATGAGAA-3' and reverse 5'-GCACTA GGAAAGCCGAGTAC-3'. The primers for $\beta$-actin were as follows: Forward 5'-TCATCACTATTGGCAACGAGC-3', and reverse 5'-AACAGTCCGCCTAGAAGCAC-3'. The amplification was performed under the following conditions: $95^{\circ} \mathrm{C}$ for $10 \mathrm{~min}$ (initial denaturation), followed by 45 cycles of $95^{\circ} \mathrm{C}$ for $10 \mathrm{sec}$ (denaturation), $60^{\circ} \mathrm{C}$ for $20 \mathrm{sec}$ (annealing) and $20^{\circ} \mathrm{C}$ for $35 \mathrm{sec}$ (extension). Melting curves were generated at $95^{\circ} \mathrm{C}$ for $15 \mathrm{sec}, 60^{\circ} \mathrm{C}$ for $60 \mathrm{sec}$ and $95^{\circ} \mathrm{C}$ for $15 \mathrm{sec}$ in order to assess the specificity of each reaction. $\beta$-actin mRNA was used as an internal control. The mRNA ratio of target gene to $\beta$-actin was calculated as the relative expression level of the target gene using the $2^{-\Delta \Delta C q}$ method (32).

Western blot analysis. Tissue samples were homogenized in homogenization buffer and centrifuged at $13,000 \mathrm{x}$ g at $4^{\circ} \mathrm{C}$ for $20 \mathrm{~min}$ to collect the supernatants. The supernatants were subjected to BCA protein assay to determine the protein concentrations of the samples. The total tissue protein was extracted and its concentration was measured by UV spectrophotometry (Shanghai Mapada Instruments Co., Ltd., Shanghai, China). Equal amounts of total protein $(20 \mu \mathrm{l})$ were separated by $10 \%$ SDS-PAGE and then transferred to a polyvinylidene difluoride membrane (EMD Millipore, Billerica, MA, USA). After blocking with 5\% nonfat milk for $2 \mathrm{~h}$, the membrane was incubated overnight with anti-IL-6 (1:2,500; cat. no. ab7737; Abcam) and anti- $\beta$-actin antibodies (1:2,500; cat. no. ab8226; Abcam) at $4^{\circ} \mathrm{C}$. This was followed by incubation with horseradish peroxidase-conjugated secondary anti-mouse antibody (1:5,000; cat. no. A32733; Pierce; Thermo Fisher Scientific, Inc.) for $1 \mathrm{~h}$ at room temperature. Band intensities were measured with ImageJ version $1.36 \mathrm{~b}$ (National Institutes of Health, Bethesda, MA, USA) and normalized to $\beta$-actin levels. Experiments were performed three times.

Statistical analysis. Values are expressed as the mean \pm standard error of the mean. SPSS 21.0 (International Business Machines Corporation, Armonk, NY, USA) was employed for statistical analysis. $\mathrm{P}<0.05$ was considered to indicate a statistically significant difference.

\section{Results}

Disease severity. To determine DAI scores, factors such as activity, body weight, fur color, grooming, diet, stool consistency and hematochezia were taken into account. Mice with no intervention had a normal body weight, shiny fur as well as a regular dietary intake and stool. However, mice treated with DSS (colitis models) were anorexic and the body weight started to decrease at days 2-3 after injection with normal saline or propylene glycol; their hair became darkened and the stool properties were gradually altered. On the fourth day of treatment, hematochezia or fecal occult blood was observed, along with marked body weight loss. However, after treatment with TL 
( 0.40 or $0.60 \mathrm{mg} / \mathrm{kg})$, dexamethasone or mesalazine, the mice showed increased body weight and dietary intake; indeed, their activity was improved, shiny hair was regained, hematochezia was alleviated and their stool gradually regained its normal consistency (Fig. 1). These findings supported the previously suggested notion that TL has a therapeutic benefit in UC.

Gross and histological observations. Next, the present study assessed the morphological alterations in the intestinal mucosa of the mice. In the blank control group, no hyperemia, edema or erosion was found. However, after treatment with DSS, obvious erosion and superficial ulceration were observed. The lesions were continuous and developed from the anus; the rectum and distal colon were mostly affected, with severe mucosal hyperemia and edema, while the proximal colon showed mild hyperemia and edema. After treatment with TL $(0.40$ or $0.60 \mathrm{mg} / \mathrm{kg})$, dexamethasone or mesalazine, the colonic mucosal injury was alleviated; the rectum and distal colon mucosae had mild hyperemia and edema, and no hyperemia or edema was observed in the proximal colon. The associated scores are shown in Table I.

For histological observation, H\&E-stained colonic mucosa specimens were prepared. The colonic mucosa was intact, without erosion or ulceration; the glands had normal morphology and were well arranged in sham control mice. After treatment with DSS, lesion, erosion and ulceration areas were observed in the colonic mucosa, with massive infiltration of lymphocytes and mononuclear cells as well as a certain number of neutrophils in the mucosa and submucosal. Lymphoid follicles were formed occasionally. The glands were deformed and disordered. However, after treatment with TL $(0.40$ or $0.60 \mathrm{mg} / \mathrm{kg})$, dexamethasone or mesalazine, the degree of inflammation, erosion and ulceration in the colonic mucosa was significantly alleviated compared with that in the saline- and propylene glycol-treated groups (Table II).

Serum IL-6 levels in mice. Next, the serum levels of IL-6 in mice were analyzed using ELISA. Serum IL-6 levels in the normal saline- and propylene glycol-treated groups were significantly higher than the blank control groups, indicating a significant increase of IL-6 induced by DSS compared with that in the control group $(\mathrm{P}<0.05)$. Serum IL-6 levels in the TL $(0.40$ and $0.60 \mathrm{mg} / \mathrm{kg}$ ), dexamethasone and mesalazine treatment groups were significantly reduced compared with those in the normal saline and propylene glycol-treated groups $(\mathrm{P}<0.05$; Table III).

Tissue mRNA and protein expression pattern of IL-6 in mice. IL-6 mRNA was barely detected in the colonic mucosa of blank control mice; however, after treatment with DSS, IL-6 gene expression levels were significantly increased $(\mathrm{P}<0.05)$. Of note, treatment with TL ( 0.40 or $0.60 \mathrm{mg} / \mathrm{kg}$ ), dexamethasone or mesalazine significantly decreased colitis-induced IL-6 mRNA levels $(\mathrm{P}<0.05)$. However, there was no significant difference in IL-6 mRNA expression levels among these abovementioned treatment groups E-H (P>0.05; Table IV).

As presented in Fig. 2 and Table V, immunohistological analysis revealed an upregulation of IL-6 in the colonic mucosa tissue samples from UC mice in the vehicle-treated groups, compared with those in the blank control $(\mathrm{P}<0.05)$. However, TL $(0.40$ and $0.60 \mathrm{mg} / \mathrm{kg})$, dexamethasone and mesalazine

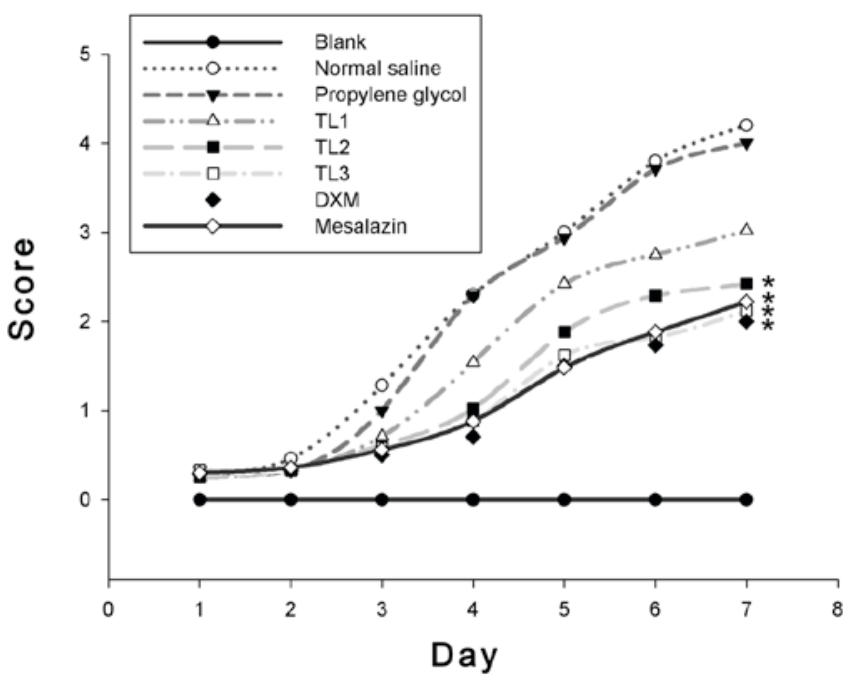

Figure 1. Disease activity indices of mice from the first day of dosing. ${ }^{*} \mathrm{P}<0.05$ vs. normal saline and propylene glycol treatment groups. TL, triptolide; DXM, dexamethasone.

treatment alleviated this UC-associated upregulation of IL-6 $(\mathrm{P}<0.05)$. However, there was no significant difference in IL-6 expression levels among the TL $(0.40$ and $0.60 \mathrm{mg} / \mathrm{kg})$, dexamethasone and mesalazine treatment groups $(\mathrm{P}>0.05)$.

To further assess the expression pattern of IL- 6 in colonic mucosa tissue samples, IL-6 protein levels were evaluated by western blot analysis. IL- 6 protein was weakly expressed in the colonic mucosa tissues of blank control mice; however, significantly higher IL-6 protein levels were found after induction of UC with DSS, and treatment with dexamethasone, mesalazine and TL $(0.40$ or $0.60 \mathrm{mg} / \mathrm{kg})$ significantly attenuated these effects (Fig. 3).

\section{Discussion}

Inflammatory bowel diseases (IBDs), including UC and Crohn's disease (CD), are characterized by remission and frequent exacerbation. Prior studies point to a profound role of a dysregulated immune system in the immunopathogenesis of IBD. The initial purpose of the immune response in IBD is to protect against foreign antigen invasion; however, as the immune response becomes dysregulated, it may elicit intestinal mucosa tissue damage. In the intestinal mucosa of IBD patients, the expression of pro-inflammatory cytokines, such as IL-1, IL-6, TNF- $\alpha$ and interferon- $\gamma$, is significantly upregulated. Aberrant activation of cytokines has a crucial role in the immunological mechanisms underlying IBD pathology (1).

$\mathrm{TL}$ is a diterpenoid isolated from the plant Tripterygium wilfordii; it inhibits T-cell proliferation, induces T-cell apoptosis, suppresses tumor angiogenesis and has anti-oxidant properties (10). Lu et al (13) reported that TL may restrain the infiltration of immune cells into corneal fibroblast tissue in virtue of the suppression of IL-6, intercellular adhesion molecule 1 and chemokines induced by lipopolysaccharide. Wang et al (14) demonstrated that arthritic ankle thickness decreased after TL treatment in a rat model of adjuvant-induced arthritis (AA). In synovial tissue samples from rats with AA, the expression of monocyte 
Table I. Gross score comparison among groups $(n=8)$.

\begin{tabular}{ll}
\hline Group & Gross score \\
\hline Blank control & $0.30 \pm 0.08^{\mathrm{a}}$ \\
Normal saline treatment & $2.92 \pm 0.30$ \\
Propylene glycol & $2.78 \pm 0.26$ \\
TL1 $(0.2 \mathrm{mg} / \mathrm{kg})$ & $2.52 \pm 0.20$ \\
TL2 $(0.4 \mathrm{mg} / \mathrm{kg})$ & $2.12 \pm 0.14^{\mathrm{a}}$ \\
TL3 $(0.6 \mathrm{mg} / \mathrm{kg})$ & $2.06 \pm 0.12^{\mathrm{a}}$ \\
Dexamethasone & $2.00 \pm 0.10^{\mathrm{a}}$ \\
Mesalazine & $1.92 \pm 0.12^{\mathrm{a}}$
\end{tabular}

Values are expressed as the mean \pm standard deviation. ${ }^{\mathrm{a}} \mathrm{P}<0.01$ vs. propylene glycol and normal saline groups. TL, triptolide.

Table II. Histological score comparison among groups $(n=8)$.

\begin{tabular}{lc}
\hline Group & Histological score \\
\hline Blank control & $0.40 \pm 0.10^{\mathrm{a}}$ \\
Normal saline treatment & $3.36 \pm 0.30$ \\
Propylene glycol & $3.10 \pm 0.26$ \\
TL1 $(0.2 \mathrm{mg} / \mathrm{kg})$ & $2.62 \pm 0.22$ \\
TL2 $(0.4 \mathrm{mg} / \mathrm{kg})$ & $1.86 \pm 0.20^{\mathrm{a}}$ \\
TL3 $(0.6 \mathrm{mg} / \mathrm{kg})$ & $1.70 \pm 0.20^{\mathrm{a}}$ \\
Dexamethasone & $1.56 \pm 0.16^{\mathrm{a}}$ \\
Mesalazine & $1.72 \pm 0.12^{\mathrm{a}}$ \\
\hline
\end{tabular}

Values are expressed as the mean \pm standard deviation. ${ }^{a} \mathrm{P}<0.01$ vs. propylene glycol and normal saline groups. TL, triptolide.

Table III. Serum IL-6 levels among groups $(n=8)$.

\section{Group}

Blank control

Normal saline treatment

Propylene glycol

TL1 $(0.2 \mathrm{mg} / \mathrm{kg})$

TL2 $(0.4 \mathrm{mg} / \mathrm{kg})$

TL3 $(0.6 \mathrm{mg} / \mathrm{kg})$

Dexamethasone

Mesalazine

Serum IL-6 levels $(\mathrm{pg} / \mathrm{ml})$

Values are expressed as the mean \pm standard deviation. ${ }^{\mathrm{a}} \mathrm{P}<0.01$ vs. propylene glycol and normal saline groups. TL, triptolide.

chemoattractant protein (MCP)-1 and macrophage inflammatory protein (MIP)-1 $\alpha$ was upregulated compared with that in normal control rats. Importantly, TL markedly restrained the AA-associated overexpression of MCP-1 and MIP-1 $\alpha$ in a dose-dependent manner. Another study by Yifan et al (15) revealed that in synovial tissue samples from rats with AA,
Table IV. IL-6 mRNA expression levels in each group $(n=8)$.

\begin{tabular}{lc}
\hline Group & IL-6 mRNA expression \\
\hline Blank control & $1.000 \pm 0.000^{\mathrm{a}}$ \\
Normal saline treatment & $2.662 \pm 0.366$ \\
Propylene glycol & $2.522 \pm 0.342$ \\
TL1 $(0.2 \mathrm{mg} / \mathrm{kg})$ & $2.022 \pm 0.320$ \\
TL2 $(0.4 \mathrm{mg} / \mathrm{kg})$ & $1.402 \pm 0.202^{\mathrm{a}}$ \\
TL3 $(0.6 \mathrm{mg} / \mathrm{kg})$ & $1.382 \pm 0.182^{\mathrm{a}}$ \\
Dexamethasone & $1.228 \pm 0.142^{\mathrm{a}}$ \\
Mesalazine & $1.326 \pm 0.150^{\mathrm{a}}$
\end{tabular}

Values are expressed as the mean \pm standard deviation. ${ }^{\mathrm{a}} \mathrm{P}<0.01$ vs. propylene glycol and normal saline groups. TL, triptolide.

Table V. Immunohistological score for IL-6 in each of the treatment groups $(n=8)$.

\begin{tabular}{lc}
\hline Group & Immunohistological score \\
\hline Blank control & $1.00 \pm 0.00^{\mathrm{a}}$ \\
Normal saline treatment & $3.88 \pm 0.38$ \\
Propylene glycol & $3.72 \pm 0.36$ \\
TL1 $(0.2 \mathrm{mg} / \mathrm{kg})$ & $2.92 \pm 0.26$ \\
TL2 $(0.4 \mathrm{mg} / \mathrm{kg})$ & $2.34 \pm 0.20^{\mathrm{a}}$ \\
TL3 $(0.6 \mathrm{mg} / \mathrm{kg})$ & $1.98 \pm 0.16^{\mathrm{a}}$ \\
Dexamethasone & $1.76 \pm 0.12^{\mathrm{a}}$ \\
Mesalazine & $1.88 \pm 0.15^{\mathrm{a}}$
\end{tabular}

Values are expressed as the mean \pm standard deviation. ${ }^{\mathrm{a}} \mathrm{P}<0.01$ vs. propylene glycol and normal saline groups. TL, triptolide.

the expression of $\mathrm{C}-\mathrm{C}$ chemokine receptor type 5 (CCR5) was elevated compared with that in normal rats. Similarly, TL markedly suppressed the overexpression of CCR5 induced by AA. Recently, Xu et al (16) reported that TL inhibited osteoclast differentiation and bone resorption in rheumatoid arthritis, and the repressive effects of T-regulatory cells on bone resorption were enhanced by TL through promoting the secretion of transforming growth factor- $\beta 1$ and IL-10. A study by Wei et al (19) indicated that TL retarded the Toll-like receptors (TLRs)/nuclear factor (NF) $-\kappa B$ signaling pathway to alleviate experimental colitis. Indeed, TL was demonstrated to inhibit the TLRs/NF- $\kappa \mathrm{B}$ pathway in cultured colonic explants from CD patients in vitro. In addition, in IL-10 $10^{-/}$mice, the expression of TLR2 and TLR4 was elevated, with TL inhibiting the TLRs/NF- $\mathrm{BB}$ signaling pathway in vivo. Li et al (21) found that TL inhibited the expression of IL-17 to alleviate spontaneous colitis in $\mathrm{C} 3 \mathrm{H} / \mathrm{HeJBirIL}-10^{-/}$mice, likely involving downregulation of the IL-6/signal transducer and activator of transcription 3 signaling pathway. Furthermore, a study by Yu et al (22) demonstrated that TL markedly reduced NF-small ka, Cyrillic B activation in the colon mucosa of IL-10 $10^{-/}$mice. In the latter study, gene expression levels of IL-12 and IL-23 in the colon were also reduced after treatment. 


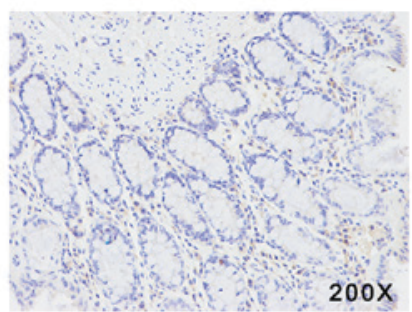

Blank control

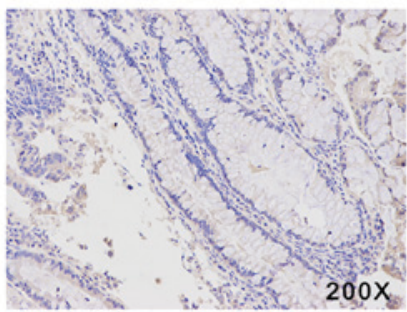

TL1 treatment

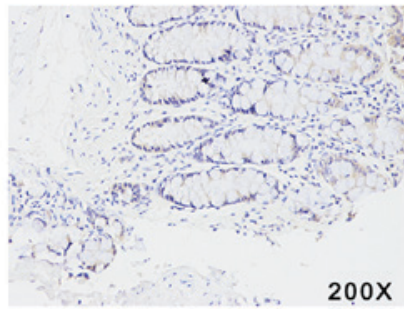

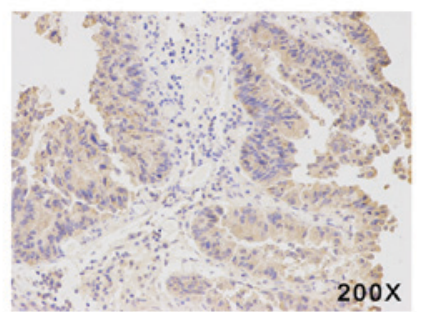

Normal saline treatment

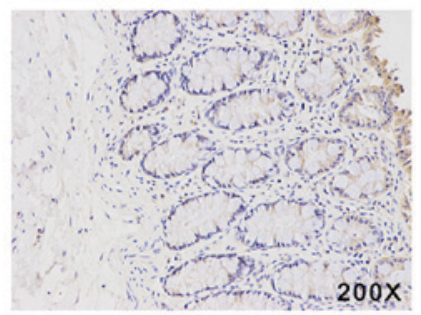

TL2 treatment

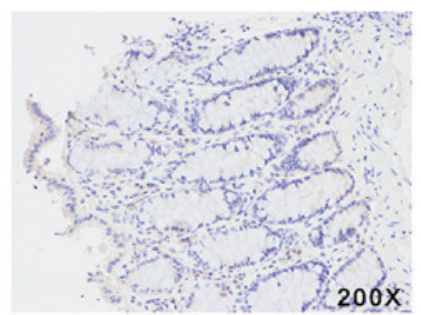

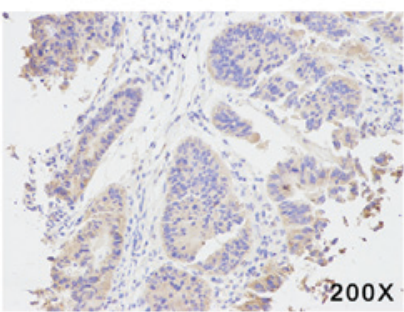

Propylene glycol treatment

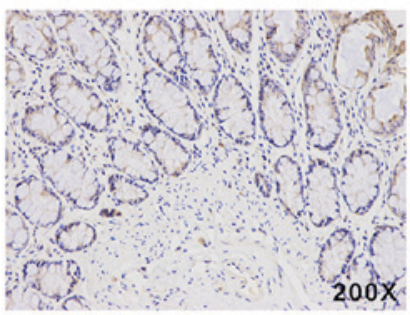

TL3 treatment

\section{Dexamethasone treatment Mesalazine treatment}

Figure 2. Immunohistochemical analysis of interleukin-6 (magnification, x200).
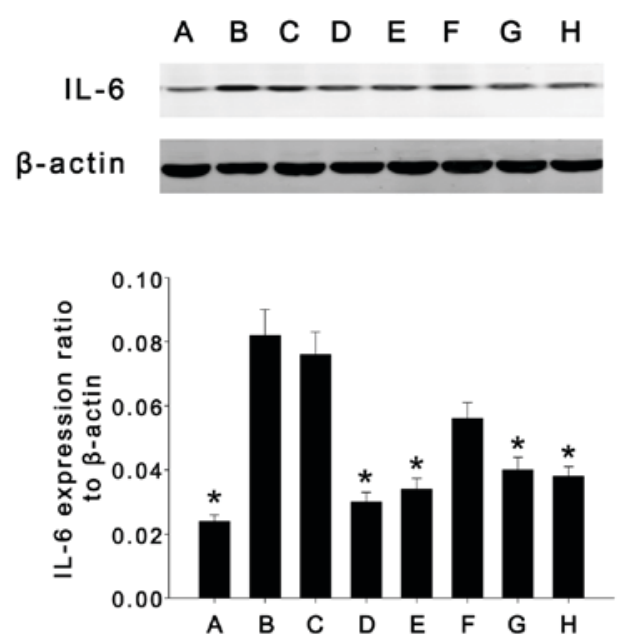

Figure 3. Expression of interleukin-6 (23 kDa) and $\beta$-actin $(47 \mathrm{kDa})$ in intestinal tissue samples determined by western blot analysis. (A) Blank control group; (B) normal saline treatment group; (C) propylene glycol treatment group; (D) dexamethasone treatment group; (E) mesalazine treatment group; (F) TL1 treatment group $(0.20 \mathrm{mg} / \mathrm{kg}) ;(\mathrm{G})$ TL2 treatment group $(0.40 \mathrm{mg} / \mathrm{kg}) ;(\mathrm{H}) \mathrm{TL} 3$ treatment group $(0.60 \mathrm{mg} / \mathrm{kg})$. Values are expressed as the mean \pm standard error of the mean. ${ }^{*} \mathrm{P}<0.05$, vs. normal saline and propylene glycol treatment groups. TL, triptolide.

The efficacy of TL treatment in reducing intestinal inflammation in IL-10 $10^{-/}$mice is due to its anti-inflammatory as well as immunosuppressive activities. A previous study by our group comparing the effects of TL and dexamethasone in mice with DSS-induced UC indicated that TL ameliorated the disease symptoms and downregulated the expression of solute carrier protein (26). A study by Tao et al (27) indicated triptolide may be a potential therapeutic agent for IBD due to its extracellular matrix protective and anti-inflammatory properties.

The present study demonstrated that after treatment with TL $(0.40$ and $0.60 \mathrm{mg} / \mathrm{kg})$, dexamethasone and mesalazine, UC in mice was greatly alleviated. Specifically, ulceration and erosion were improved, serum levels of IL-6 were significantly decreased, and the expression of IL- 6 in colon tissues was also downregulated. These findings indicated that TL treatment had a similar therapeutic effect to that of dexamethasone and mesalazine, which may be exerted through inhibition of the overexpression of IL-6.

In conclusion, the presents study revealed that treatment with TL, dexamethasone and mesalazine attenuated bowel tissue inflammation; thus, TL may represent an efficient means for treating UC. Its therapeutic effect may involve restraining IL-6 expression by reducing various types of chemokines, which may offer an alternative option for UC patients. However, further studies are warranted to clarify the molecular mechanisms underlying the therapeutic role of TL in UC.

\section{Acknowledgements}

This study was supported by a grant from the Social Application Research Plans Foundation of Nantong (grant no. 2012074). 


\section{References}

1. Hur SJ, Kang SH, Jung HS, Kim SC, Jeon HS, Kim IH and Lee JD: Review of natural products actions on cytokines in inflammatory bowel disease. Nutr Res 32: 801-816, 2012.

2. Powell N, Lo JW, Biancheri P, Vossenkämper A, Pantazi E, Walker AW, Stolarczyk E, Ammoscato F, Goldberg R, Scott P, et al: Interleukin 6 increases production of cytokines by colonic innate lymphoid cells in mice and patients with chronic intestinal inflammation. Gastroenterology 149: 456-467.e15, 2015.

3. Shaker A, Gargus M, Fink J, Binkley J, Darwech I, Swietlicki E, Levin MS and Rubin DC: Epimorphin(-/-) mice are protected, in part, from acute colitis via decreased interleukin 6 signaling. Transl Res 164: 70-83, 2014.

4. Kasinathan NK, Subramaniya BR, Pandian I and Sivasithamparam ND: Aegle marmelos fruit extract abates dextran sodium sulfate induced acute colitis in mice: Repression of pro-inflammatory cytokines during colonic inflammation. Biomed Prev Nutr 4: 307-317, 2014.

5. Blumberg R, Cho J, Lewis J and Wu G: Inflammatory bowel disease: An update on the fundamental biology and clinical management. Gastroenterology 140: 1701-1703, 2011.

6. Strober W and Fuss IJ: Proinflammatory cytokines in the pathogenesis of inflammatory bowel diseases. Gastroenterology 140: $1756-1767,2011$.

7. Roberts-Thomson IC, Fon J, Uylaki W, Cummins AG and Barry S: Cells, cytokines and inflammatory bowel disease: A clinical perspective. Expert Rev Gastroenterol Hepatol 5: 703-716, 2011

8. Mitsuyama K, Toyonaga A, Sasaki E, Ishida O, Ikeda H, Tsuruta O, Harada K, Tateishi H, Nishiyama T and Tanikawa K: Soluble interleukin-6 receptors in inflammatory bowel disease: Relation to circulating interleukin-6. Gut 36: 45-49, 1995.

9. Wine E, Mack DR, Hyams J, Otley AR, Markowitz J, Crandall WV, Leleiko N, Muise AM, Griffiths AM and Turner D: Interleukin-6 is associated with steroid resistance and reflects disease activity in severe pediatric ulcerative colitis. J Crohns Colitis 7: 916-922, 2013.

10. Yang S, Chen J, Guo Z, Xu XM, Wang L, Pei XF, Yang J, Underhill CB and Zhang L: Triptolide inhibits the growth and metastasis of solid tumors. Mol Cancer Ther 2: 65-72, 2003.

11. Lu Y, Fukuda K, Nakamura Y, Kimura K, Kumagai N and Nishida T: Inhibitory effect of triptolide on chemokine expression induced by proinflammatory cytokines in human corneal fibroblasts. Invest Ophthalmol Vis Sci 46: 2346-2352, 2005.

12. Tang W, Zhou R, Yang Y, Li YC, Yang YF and Zuo JP: Suppression of (5R)-5-hydroxytriptolide (LLDT-8) on allograft rejection in full MHC-mismatched mouse cardiac transplantation. Transplantation 81: 927-933, 2006.

13. Lu Y, Liu Y, Fukuda K, Nakamura Y, Kumagai N and Nishida T: Inhibition by triptolide of chemokine, proinflammatory cytokine, and adhesion molecule expression induced by lipopolysaccharide in corneal fibroblasts. Invest Ophthalmol Vis Sci 47: 3796-3800, 2006.

14. Wang Y, Wei D, Lai Z and Le Y: Triptolide inhibits CC chemokines expressed in rat adjuvant-induced arthritis. Int Immunopharmacol 6: 1825-1832, 2006.

15. Yifan W, Dengming W, Zheng L, Yanping L and Junkan S: Triptolide inhibits CCR5 expressed in synovial tissue of rat adjuvant-induced arthritis. Pharmacol Rep 59: 795-799, 2007.

16. Xu H, Zhao H, Lu C, Qiu Q, Wang G, Huang J, Guo M, Guo B, Tan Y and Xiao C: Triptolide inhibits osteoclast differentiation and bone resorption in vitro via enhancing the production of IL-10 and TGF- $\beta 1$ by regulatory T cells. Mediators Inflamm 2016: 8048170, 2016
17. Liu Y, Chen Y, Liu FQ, Lamb JR and Tam PK: Combined treatment with triptolide and rapamycin prolongs graft survival in a mouse model of cardiac transplantation. Transpl Int 21: 483-494, 2008.

18. Tao X, Fan F, Hoffmann V, Gao CY, Longo NS, Zerfas P and Lipsky PE: Effective therapy for nephritis in (NZB x NZW)F1 mice with triptolide and tripdiolide, the principal active components of the Chinese herbal remedy Tripterygium wilfordii Hook F. Arthritis Rheum 58: 1774-1783, 2008

19. Wei X, Gong J, Zhu J, Wang P, Li N, Zhu W and Li J: The suppressive effect of triptolide on chronic colitis and TNF-alpha/TNFR2 signal pathway in interleukin-10 deficient mice. Clin Immunol 129: 211-218, 2008.

20. Kizelsztein P, Komarnytsky S and Raskin I: Oral administration of triptolide ameliorates the clinical signs of experimental autoimmune encephalomyelitis (EAE) by induction of HSP70 and stabilization of NF-kappaB/IkappaBalpha transcriptional complex. J Neuroimmunol 217: 28-37, 2009.

21. Li Y, Yu C, Zhu WM, Xie Y, Qi X, Li N and Li JS: Triptolide ameliorates IL-10-deficient mice colitis by mechanisms involving suppression of IL-6/STAT3 signaling pathway and down-regulation of IL-17. Mol Immunol 47: 2467-2474, 2010.

22. Yu C, Shan T, Feng A, Li Y, Zhu W, Xie Y, Li N and Li J: Triptolide ameliorates Crohn's colitis is associated with inhibi-

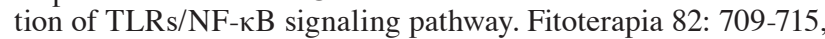
2011.

23. Wu C, Xia Y, Wang P, Lu L and Zhang F: Triptolide protects mice from ischemia/reperfusion injury by inhibition of IL-17 production. Int Immunopharmacol 11: 1564-1572, 2011.

24. Wang J, Shi ZQ, Xu X, Xin GZ, Chen J, Qi LW and Li P: Triptolide inhibits amyloid- $\beta$ production and protects neural cells by inhibiting CXCR2 activity. J Alzheimers Dis 33: 217-229, 2013.

25. Wu R, Li Y, Guo Z, Gong J, Zhu W, Li N and Li J: Triptolide ameliorates ileocolonic anastomosis inflammation in IL-10 deficient mice by mechanism involving suppression of miR-155/SHIP-1 signaling pathway. Mol Immunol 56: 340-346, 2013.

26. Zhang H, Gong C, Qu L, Ding X, Cao W, Chen H, Zhang B and Zhou G: Therapeutic effects of triptolide via the inhibition of IL-1 $\beta$ expression in a mouse model of ulcerative colitis. Exp Ther Med 12: 1279-1286, 2016

27. Tao Q, Wang B, Zheng Y, Li G and Ren J: Triptolide ameliorates colonic fibrosis in an experimental rat model. Mol Med Rep 12: 1891-1897, 2015

28. Stevceva L, Pavli P, Husband AJ and Doe WF: The inflammatory infiltrate in the acute stage of the dextran sulphate sodium induced colitis: B cell response differs depending on the percentage of DSS used to induce it. BMC Clin Pathol 1: 3, 2001

29. Murano M, Maemura K, Hirata I, Toshina K, Nishikawa T, Hamamoto N, Sasaki S, Saitoh O and Katsu K: Therapeutic effect of intracolonically administered nuclear factor kappa B (p65) antisense oligonucleotide on mouse dextran sulphate sodium (DSS)-induced colitis. Clin Exp Immunol 120: 51-58, 2000.

30. Ekström GM: Oxazolone-induced colitis in rats: Effects of budesonide, cyclosporin A, and 5-aminosalicylic acid. Scand J Gastroenterol 33: 174-179, 1998.

31. Boirivant M, Fuss IJ, Ferroni L, De Pascale M and Strober W: Oral administration of recombinant cholera toxin subunit B inhibits IL-12-mediated murine experimental (trinitrobenzene sulfonic acid) colitis. J Immunol 166: 3522-3532, 2001.

32. Livak KJ and Schmittgen TD: Analysis of relative gene expression data using real-time quantitative PCR and the 2(-Delta Delta C(T)) Method. Methods 25: 402-408, 2001 